OECDpublishing

\title{
ISRAEL'S GREEN TAX ON CARS
}

LESSONS IN ENVIRONMENTAL POLICY REFORM

OECD ENVIRONMENT POLICY PAPER

July $2016 n^{\circ} 05$ 


\section{Israel's Green Tax on Cars}

\section{Lessons in Environmental Policy Reform}

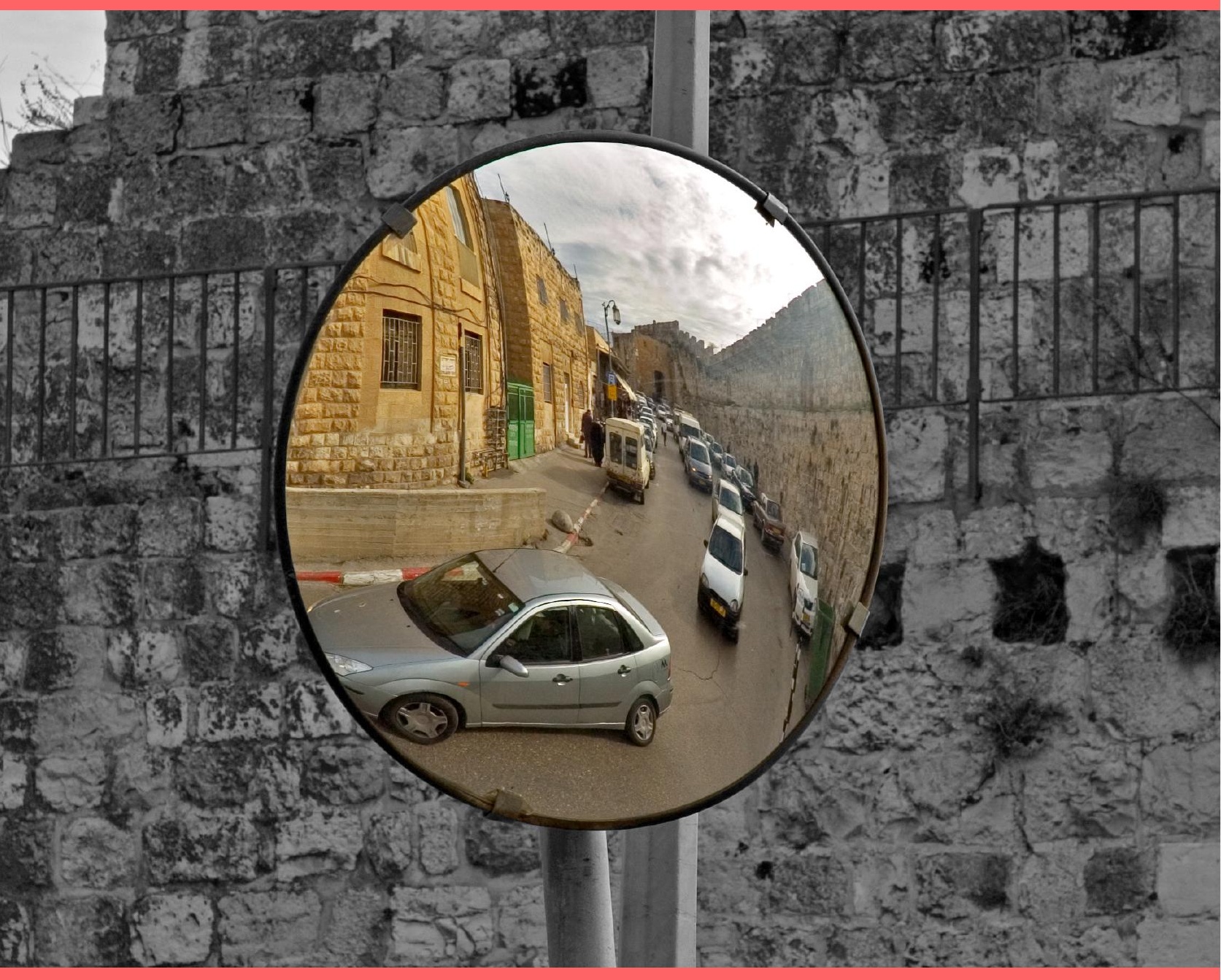

OECD ENVIRONMENT POLICY PAPER NO. 5

JUNE 2016

\section{(2) OECD




\section{Disclaimers}

The OECD Environmental Policy Papers are published on the responsibility of the SecretaryGeneral of the OECD. The opinions expressed and arguments employed herein do not necessarily reflect the official views of the Organisation or of the governments of its member countries.

This document and any map included herein are without prejudice to the status of or sovereignty over any territory, to the delimitation of international frontiers and boundaries and to the name of any territory, city or area.

The statistical data for Israel are supplied by and under the responsibility of the relevant Israeli authorities. The use of such data by the OECD is without prejudice to the status of the Golan Heights, East Jerusalem and Israeli settlements in the West Bank under the terms of international law.

\section{Copyright}

You can copy, download or print OECD content for your own use, and you can include excerpts from OECD publications, databases and multimedia products in your own documents, presentations, blogs, websites and teaching materials, provided that suitable acknowledgment of OECD as source and copyright owner is given. All requests for public or commercial use and translation rights should be submitted to rights@oecd.org. Requests for permission to photocopy portions of this material for public or commercial use shall be addressed directly to the Copyright Clearance Center (CCC) at info@copyright.com or the Centre français d'exploitation du droit de copie (CFC) at contact@cfcopies.com. 


\section{Israel's Green Tax on Cars \\ Lessons in Environmental Policy Reform}

OECD ENVIRONMENT POLICY PAPER NO. 5

JUNE 2016

\section{Contents}

Overview 3

The initial policy challenge: A tax to encourage low-emission car purchases 4

Designing a green car tax 6

Environmental, economic and social impacts 13

Comparison with other countries 22

Lessons learned 24

Notes 26

$\begin{array}{ll}\text { References } & 28\end{array}$ 


\section{Israel's Green Tax on Cars}

\section{Lessons in Environmental Policy Reform}

\section{OVERVIEW}

\section{The challenge}

From the start of the new millennium, Israel had been facing growing environmental, social and economic costs from its road transport, especially the large share of old, polluting and unsafe private cars on the roads - the consequence of high car prices (due to a purchase tax rate of 95\%). Emission standards, annual emission checks and other regulatory measures were not enough to encourage people to buy less polluting cars. Nor did these measures deal with the high cost to society of using a car - noise, local air pollution, greenhouse gas emissions, congestion, accidents, and wear and tear to infrastructure. Economic measures were called for to influence consumers to buy cars with lower pollution levels than those required by law.

\section{The policy response}

The government formed a broad-based inter-ministerial commission to explore possible solutions. The commission designed a unique Green Tax scheme - launched in 2009 and updated twice since - to encourage consumers to choose less polluting cars. Unlike many similar schemes across the $O E C D$, this innovative scheme aimed to reduce all polluting vehicle emissions, not only carbon dioxide $\left(\mathrm{CO}_{2}\right)$, by adjusting the vehicle purchase tax to differentiate car models according to their relative impacts on society from five key pollutants (carbon monoxide, nitrogen oxides, hydrocarbons, particulate matter and carbon dioxide).

\section{The impact}

The Green Tax provided a transparent and comprehensive way of reflecting the level of pollution in the final price of the car. The effect on the purchases of cleaner vehicles was tremendous. By 2014, around $83 \%$ of all new cars were in the lowest pollution grades - compared to $19 \%$ in 2009. There was an impressive $21 \%$ reduction in average $\mathrm{CO}_{2}$ emissions per car, and other per-car emissions also fell, particularly $\mathrm{NO}_{x}$ and $\mathrm{PM}$. However, because the tax reform essentially cut the price of the average family car it led to an increase in car purchases, a rise in emissions overall, as well as other secondary effects like congestion. Nevertheless, overall $\mathrm{NO}_{\mathrm{X}}$ and $\mathrm{PM}$ emissions increased by a lower degree than $\mathrm{CO}_{2}$ emissions, and PM emissions even decreased.

\section{Key messages}

Israel's Green Tax reform was successful in shifting demand towards less polluting vehicles, proving the efficiency of economic incentives in changing behaviour. There are many lessons to be drawn from Israel's experience for other public administrations designing similar schemes. A key lesson is that care is needed to avoid reducing average car prices to the point where car sales are stimulated and any emission reduction benefits are outweighed. The tax rate should be reviewed and adjusted regularly. Any increase in car-related taxation should be complemented by policies that offer viable alternatives to the car, such as investing in efficient public transport, widespread cycling lanes, and localised business areas and entertainment facilities. 


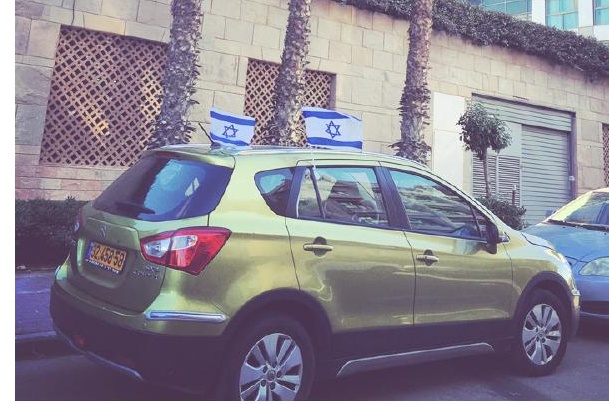

In recent decades, Israel's growing population and rising incomes have seen consumption increase substantially, bringing with it considerable pressure on the environment. One of the main environmental pressures is from the ever-increasing transport activity, especially the use of private vehicles.

Although travelling in a private vehicle brings benefits to the individual using it, this entails costs to society as a whole. These social costs extend beyond the private costs of the car and the fuel borne by the car user, imposing a burden on public health and the environment. Transport involves noise, local air pollution, and contributes to climate change, congestion, accidents, and wear and tear to infrastructure. All these negatively affect public health and quality of life in general, a fact not taken into account when an individual chooses whether or not to buy a car. This is known as a "market failure", because the price of a car does not fully reflect the social costs of using it.

Governments can correct market failures like these through policies that ensure that the actual costs to society are incorporated within the price of a car, thus influencing consumers' purchases. This paper describes how Israel developed an innovative scheme to encourage consumers to choose less polluting cars. The Green Tax scheme targets reductions in all polluting vehicle emissions, not only carbon dioxide $\left(\mathrm{CO}_{2}\right)$. The paper outlines the design process, reflects on the challenges encountered and the environmental, economic and social impacts. It concludes by discussing the wider lessons that are raised for other governments seeking to tackle similar environmental problems. 
Car tax in Israel has historically been high. Until 2009, the purchase tax rate was 95\% of the private car value, and $75 \%$ for commercial vehicles. This was one of the highest tax rates amongst OECD countries, with the exceptions of Denmark and Norway (Box 1). Although the high tax meant that Israel had one of the lowest rates of motorisation in the OECD, and cars were viewed as luxury items, it also meant that there was a large share of old, unsafe and polluting cars on the roads. Israel was also using direct regulatory measures (such as emission standards) to manage vehicle emissions. Imposing standards, however, was not proving to be the best policy. Once standards are met, there are no incentives to reduce fuel use or emissions further or to develop new technologies (Greene et al., 2005). Emission standards, enforcing annual emission checks and other regulatory measures adopted in Israel were not enough to create shifts in demand. Neither did they deal with the high cost to society of using a car - which is much more substantial than the tax paid on it. Economic measures were called for to influence consumers to buy cars with lower pollution levels than those required by law.

\section{Box 1 | The Israeli car market}

The Israeli car market is relatively small, and relies entirely on imports for new cars. There were 3 million vehicles in Israel in 2014, 2.5 million of which were private cars (CBS, 2015a). New private car registrations in 2014 reached 239 000, comparable with Norway, Denmark, Czech Republic and New Zealand. Israel also has a similar volume of road traffic as these countries. With few tax rules favouring diesel cars, the passenger car market in Israel is dominated by petrol cars ( $96.5 \%$ of all private cars) unlike in the European Union (EU), where $53 \%$ of new sales in 2014 were of diesel cars.

However, Israel is characterised by two factors that make it stand out. First, it has the greatest average traffic density among OECD countries (Figure 2) and one of the highest annual average distances travelled per vehicle. Suburbanisation, combined with limited public transport, create a high dependency on cars and help to explain the high average distances travelled.

Second, and paradoxically, Israel has had one of the lowest motorisation rates in the OECD (281 private cars per 1000 inhabitants). One of the reasons for the low motorisation rate is the high consumer price of acquiring a car, second only to Denmark, and is explained by the high tax rate on cars. 


\section{Figure 2 | Israel's traffic density is one of the highest in the OECD ${ }^{\mathrm{ii}}$ 2014 or latest available}

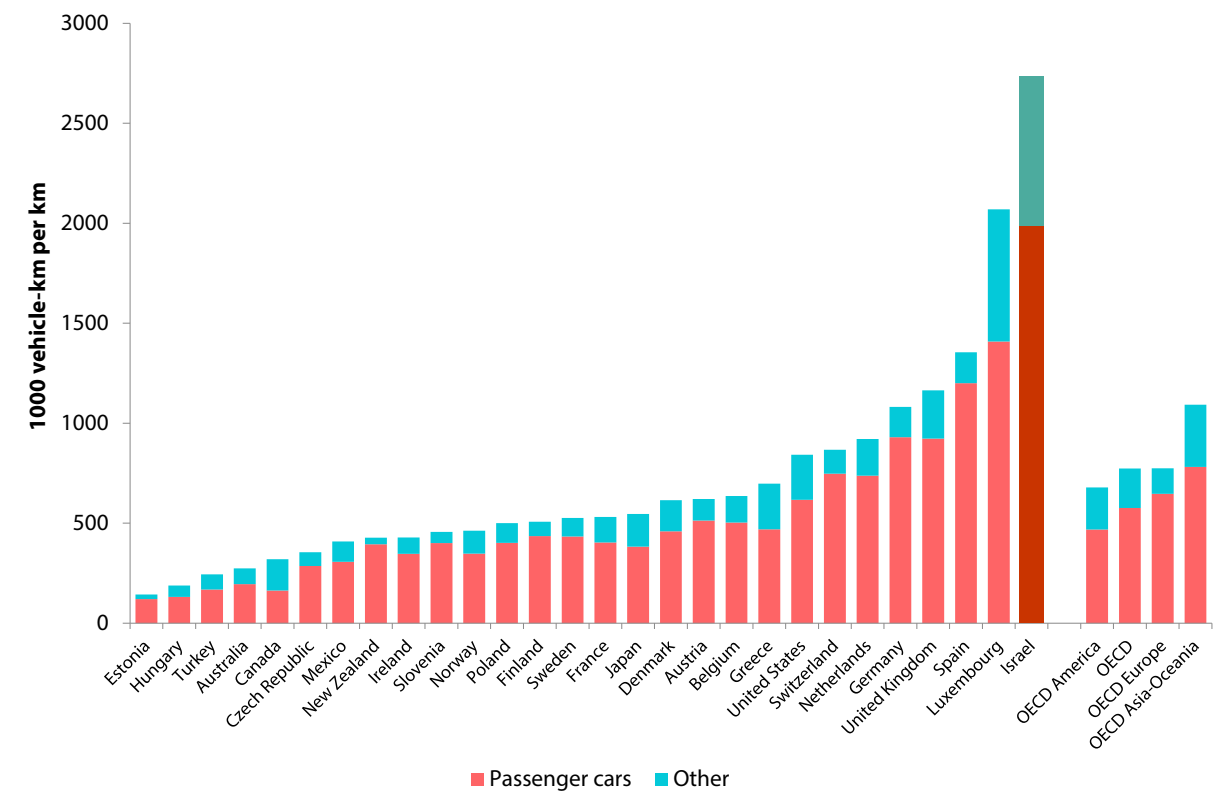

1. Source: for Israel: CBS (2015b), Kilometers Travelled 2014, www.cbs.gov.il/publications15/1621/pdf/t_07.pdf; for the EU and the United States: FT (2015), "VW scandal set to choke diesel car industry," Financial Times, 22 September 2015, http://tinyurl.com/hxxatpz.

ii. Source: OECD (2015), Environment at a Glance 2015: OECD Indicators, OECD Publishing, Paris,

http://dx.doi.org/10.1787/9789264235199-en.

\section{Designing a green car tax}

In 2006, an inter-ministerial commission was set up by the Israeli government to discuss how to deal with the external costs of road transport, one of the main subjects being the application of green taxation on cars. The commission brought together the ministries of Finance, Transport and Road Safety, National Infrastructure, and Environmental Protection, as well as external experts from various fields - car engineers, industry and management engineers and economists.

The commission estimated the external effects from transportation to be around $6 \%$ of GDP in 2004 (Table 1). These costs were compared to the total revenues received by the state from the purchase tax on vehicles and vehicle parts, plus the annual road tax and taxes on fuel, totalling 3.4\% of GDP in 2004. This implied that society subsidises private car use by at least $2.6 \%$ of GDP. These costs are imposed on the segment of the population which does not use the car, or uses it at a low rate, and include increased medical expenditure, reduced property values (in noisy and polluted areas), and others. 


\section{Table 1 | The external costs of road transport}

\begin{tabular}{|c|c|}
\hline Category & Cost estimate ( $\%$ of GDP) \\
\hline Accidents & 0.67 \\
\hline Noise & 0.36 \\
\hline Air pollution & 2.08 \\
\hline Climate change & 0.18 \\
\hline Congestion & 1.92 \\
\hline Infrastructure building and maintenance & 0.34 \\
\hline Value of free parking & 0.49 \\
\hline Total & 6.04 \\
\hline
\end{tabular}

Source: Green Tax Report (2008), "Report of the inter-ministerial commission for Green Taxation," http://taxes.gov.il/ About/Documents/DochotVaadot/misui150108_11.pdf.

Air pollution costs are caused by the emission of air pollutants such as carbon monoxide (CO), nitrogen oxides $\left(\mathrm{NO}_{\mathrm{x}}\right)$, hydrocarbons $(\mathrm{HC})$, particulate matter $(\mathrm{PM})$ and $\mathrm{CO}_{2}$ and consist of health costs, building and material damage through soiling and corrosive processes, crops damaged by acid deposition, and damage to ecosystems - soil and water (Table 2). Health costs (mainly caused by PM from exhaust emissions or transformation of other pollutants) are by far the most important cost linked to air pollution. The commission chose to focus on the environmental effects of transportation due to their high costs to public health (above $2 \%$ of GDP; see Table 1 ), which were aggravated by the Israeli climate and high population density. 


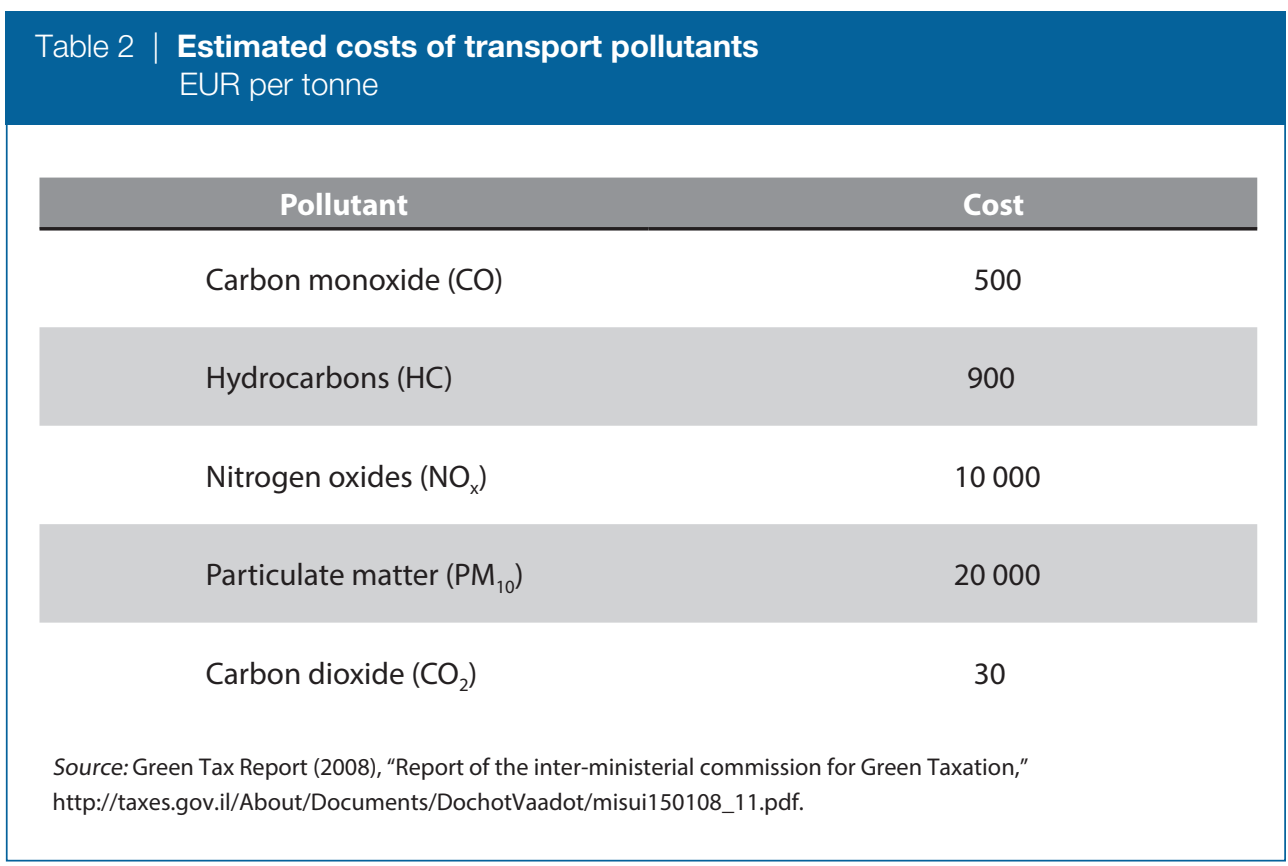

The commission explored several types of instruments which could better reflect these costs in the market price of vehicles, including linking a tax to fuel consumption, engine size and type. In the end it was decided to create a system that would use variations in tax levels to differentiate car models by the level of pollution, taking into account all five pollutants listed in Table 2.

In August 2009, the government brought in a "green reform" based on the recommendations of the commission. This adjusted the vehicle purchase tax according to 15 pollution grades, calculated by weighing all relevant and measureable emissions (carbon monoxide, nitrogen oxides, hydrocarbons, particulate matter and carbon dioxide) by each pollutant's relative cost to society (Box 2). The goal was to create a differentiation between various levels of emission, while keeping tax revenues unchanged. The government mandated the Minister of Transport to require car manufacturers to report on the levels of emissions of five major pollutants for each car model. New tax incentives to favour vehicles with enhanced safety mechanisms were also introduced. 


\section{Box 2 | How is the green grade calculated?}

The tax levied on each vehicle depends on its emission level, evaluated during the process of approving the prototype for each vehicle model. The total level of emissions - or the "green grade" - is then calculated, weighed by the costs of the five pollutants covered. The grades are split into 15 tax bands, ranging from band 1 (no emissions, e.g. electric vehicles), to band 15 (the most polluting). The maximum purchase tax was set at $83 \%$ with rebates being given to all vehicles with a pollution rating below 15 (Table 3).

In order to encourage the purchase of hybrid and electrical cars, the tax rate was set at $30 \%$ for hybrids and $10 \%$ for plug-in vehicles. As a result, the prices of less-polluting vehicles were lowered, while the more polluting vehicles were now more expensive.

Table 3 | Pollution rating, green grade, tax rebate, share of sales and effective purchase tax

\begin{tabular}{lcccc} 
Pollution rating & Green Grade & $\begin{array}{c}\text { Rebate (ILS, } \\
2009 \text { prices) }\end{array}$ & $\begin{array}{c}\text { \% of sales in } \\
2009 *\end{array}$ & $\begin{array}{c}\text { Effective purchase } \\
\text { tax rate }\end{array}$ \\
\hline $\begin{array}{l}1 \text { (no emissions, } \\
\text { e.g. electric) }\end{array}$ & $0-50$ & n/a & $0.0 \%$ & $10 \%$ \\
\hline 2 (hybrid) & $51-130$ & n/a & $1.4 \%$ & $30 \%$ \\
\hline 2 & $51-130$ & 15000 & $0.3 \%$ & $38 \%$ \\
\hline 3 & $131-150$ & 13750 & $0.9 \%$ & $50 \%$ \\
\hline 4 & $151-170$ & 12000 & $10.4 \%$ & $54 \%$ \\
\hline 5 & $171-175$ & 10500 & $6.1 \%$ & $58 \%$ \\
\hline 6 & $176-180$ & 9250 & $11.5 \%$ & $60 \%$ \\
\hline 7 & $181-185$ & 8250 & $8.6 \%$ & $64 \%$ \\
\hline 8 & $186-190$ & 7250 & $9.4 \%$ & $67 \%$ \\
\hline 9 & $191-195$ & 6500 & $5.9 \%$ & $70 \%$ \\
\hline 10 & $196-200$ & 5500 & $13.1 \%$ & $71 \%$ \\
\hline 11 & $201-205$ & 5000 & $3.4 \%$ & $73 \%$ \\
\hline 12 & $206-210$ & 4000 & $6.9 \%$ & $74 \%$ \\
\hline 15 & $211-220$ & 3250 & $5.1 \%$ & $77 \%$ \\
\hline
\end{tabular}

* Calendar year, includes 5 months of Green Tax. ILS: New Israeli sheqels. The exchange rate was EUR 1 = ILS 4.288 (12 May 2016).

Source: Israeli Tax Authority (2010), “Taxes and overview of the car sector, 2010”, Tax Authority. 
Apart from the main reform to the purchase tax, the commission proposed several other measures to deal with transport externalities (of these, only the vehicle scrapping scheme has been implemented to date):

- Congestion charges, differentiated according to places and times of travel, distance and particular lanes.

- A tax on heavy vehicles and taxis, differentiated according to levels of pollution (the purchase tax on these vehicles was $0 \%$ in 2008). ${ }^{2}$

- Tax credits for the use of "green" fuels like bio-diesel.

- A scrapping scheme for older vehicles.

- A higher annual road tax for older cars to reflect their higher pollution levels.

The modification of the vehicle purchase tax provided a transparent and comprehensive way of factoring the level of pollution into the final price of the car, with each pollutant weighed by their relative social costs.

Implementing the reform required strong support from all ministries involved. A major effort was required to present the conceptual change to car importers, politicians and the public. A great deal was also invested in public relations to describe the benefits of the tax, which by many was perceived as yet another attempt to increase tax revenues. A number of the most popular car models' prices were about to increase - mostly large family, luxury and sport cars - but for many models, the retail price was actually reduced. It became compulsory to mark the green grade and fuel consumption in every vehicle advertisement, at every point of sale and on the Ministry of Transport website. Since consumers are not immediately aware of the tax rebate, and see only the final price of a car (with the tax rebate already applied), the inclusion of clear notification of the vehicle's green grade on every advertisement was extremely important for increasing public awareness, and influencing their choice of a more efficient and less polluting car.

The reform met with opposition from the general public and particularly from some of the car importers, who feared an unfavourable change in their market shares. They questioned the legality of a differentiating tax that would cause a "distortion" in demand, and pushed for taxes based on engine efficiency and $\mathrm{CO}_{2}$ emissions, resembling European schemes. The opposition was particularly vociferous from the importers of models originating in the $\mathrm{EU}$, where manufacturers had perfected the production of $\mathrm{CO}_{2}$-efficient diesel engines for a European market committed to reduce $\mathrm{CO}_{2}$ emissions. 
The announcement of the tax modification created a substantial stir in the car market. In the few months leading up to the introduction of the reform there were increased sales of all vehicles whose retail price was expected to rise. Personal imports of luxury cars also increased. After that, the public quickly adjusted to the change. Criticism is still heard in various circles, touching on the social and fiscal aspects of the tax; but this is expected for any major change, particularly one initiated by the Tax Authority.

\section{An evolving policy}

While the short-term effect of the Green Tax reform was remarkable - prompting a vast shift in demand towards less polluting cars (see below) - it became a victim of its own success. With the average tax per car lower than in the past, private cars became more affordable. The motorisation rate increased too fast for the infrastructure to keep up. Furthermore, an increase in the total number of cars caused total emissions to rise - even though an average car was less polluting. The decrease in the total tax revenues meant that there was a smaller budget available to deal with the increased pollution and infrastructure needs.

The government decided that the formula needed to be adapted to deal with these challenges and to better reflect the Israeli context. The initial Green Tax report (2008) had used the costs of external effects which were reported in studies conducted in Europe, transferred them to Israel and adjusted them for income and inflation. The Department of Economy and Standards at the Ministry of Environmental Protection commissioned a special analysis to update the parameters of the green grade formula based on a more accurate estimation of the external costs of pollution in Israel (Becker et al., 2012). The analysis collected the results from multiple studies across the world and transferred them to Israel using a meta-analysis benefit transfer approach. ${ }^{3}$ Benefit transfer uses the economic parameters estimated elsewhere and transfers them to a different location by adjusting the variables, such as population size, age, density, and so on. According to the pollutant evaluated, it is important to take into account the sector, the size of the affected population, and the percentage of weaker groups (children and the elderly). The costs to the environment, flora and fauna were not considered. Therefore the costs evaluated in the study are underestimated.

This study led to an updated Green Grade formula being applied from August 2013, which added new cost per tonne weightings to each of the five pollutants, and modified the pollution level brackets to create more differentiation within the lower grades (Table 4). All the estimated costs were adjusted for changes in population, inflation and real GDP since 2008. Since $\mathrm{CO}_{2}$ influences global climate changes rather than causing local pollution, there is no direct effect on public health so no Israel-specific adjustments were required for this pollutant. 


\section{Table 4 | Comparison between the 2009 Green Grade formula weights and the} 2013 update, Costs (EUR per tonne)

\begin{tabular}{|ccc|}
\hline & 2009 & 2013 \\
\hline $\mathrm{CO}$ & 500 & 1042 \\
$\mathrm{HC}$ & 900 & 21454 \\
$\mathrm{NO}_{\mathrm{x}}$ & 10000 & 75461 \\
$\mathrm{PM}_{10}$ & 20000 & 145772 \\
$\mathrm{CO}_{2}$ & 30 & 103 \\
\hline
\end{tabular}

The main differences between the old and the new formulas were the increased implied costs of PM, which is extremely dangerous to human health and ecosystems (penetrating deep into lungs and capable of causing cancer among other problems) and $\mathrm{NO}_{\mathrm{x}}$ (linked to breathing problems and decreased lung function). $\mathrm{NO}_{\mathrm{x}}$ emissions are also an important source of secondary formation of PM.

In 2013, when the update came into force, the median car was in band 4 . The new weighting shifted the median to pollution band 6 , thus reducing the rebates given to the same car model. ${ }^{4}$ Effectively, all grades were shifted upward, and a higher grade was implicitly attached to diesel vehicles as they emit more $\mathrm{PM}$ and $\mathrm{NO}_{\mathrm{x}}$ (Figure 3). It was also decided to update the formula every two years - in January 2015 the Green Tax was therefore updated again, adjusting all the costs for changes in real GDP and population increase, as was done in 2013. Relative weights for each pollutant did not change. However, the update essentially increased the grade for the same car, potentially moving it to a higher tax bracket.

\section{Figure 3 | Green grade before and after formula update, 2012 vehicle import data*}

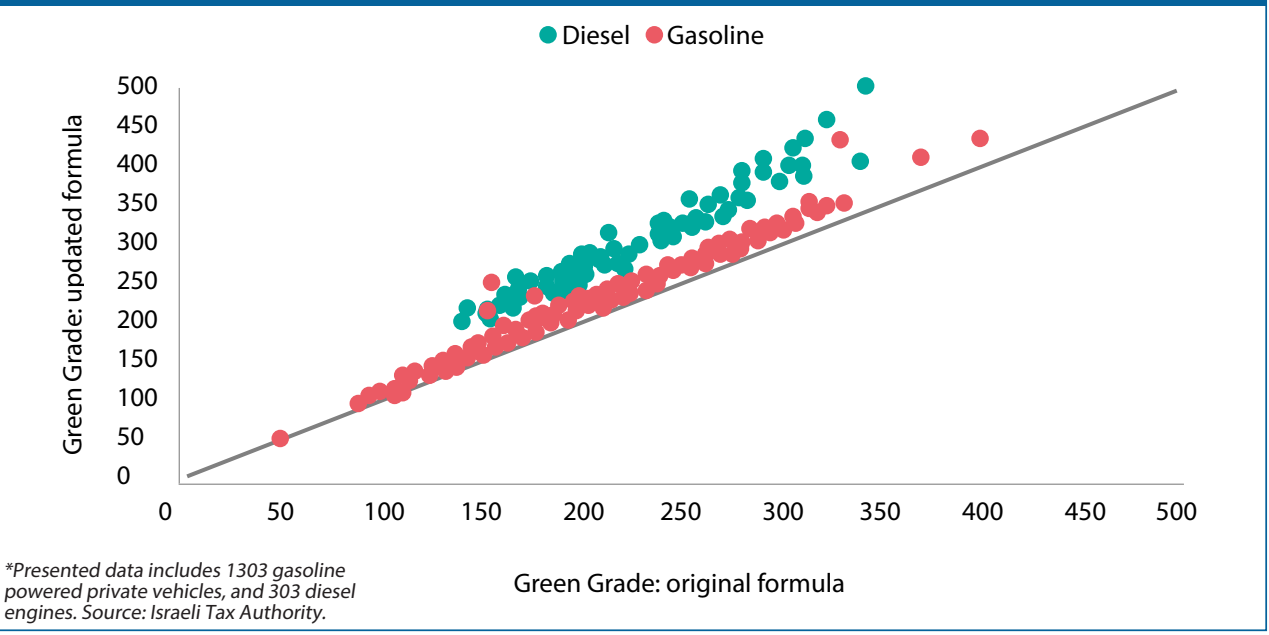




\section{Environmental, economic and social impacts}

When attempting to evaluate the effects of a policy, multiple factors have to be taken into account. The decision to purchase a car, including its size, type, features and price, is complex and is usually taken over a prolonged period of time. Over the study period there were also several changes in the Israeli market, both in terms of supply and demand, and changes in legislation. Several other external events (new regulations in the EU and other non-member countries that affected manufacturing standards, consumer income changes, local conflicts (Lebanon War, intifada), the global financial crisis of 2007-08, changes in world prices of gasoline and availability of alternatives like public transport, etc.) all affected demand in terms of engine size and pollution levels.

The sections which follow summarise in-depth analysis and modelling conducted by Victoria Roshal (an independent consultant) and Alfred Tovias (The Hebrew University of Jerusalem) designed to take into account these factors in order to assess the environmental, social and economic impacts of the green car tax reform. For further details, please refer to Roshal and Tovias (2016).

\section{Environmental impacts}

The apparent effect of the policy on the composition of vehicles by their pollution level was tremendous. From 2010, there was a significant reduction in sales of cars with pollution grades 10-15. The average pollution grade fell from 10 in the first seven months of 2009 to 7 in 2010 and down to 4 in 2012. By 2013, nearly 70\% of all new cars fell into the first five pollution levels - compared to $19 \%$ of cars in 2009. The formula update in August 2013 had an even stronger impact, increasing the share of imported cars in levels 1-5 from 49\% (according to new formula) in 2013 to $83 \%$ in 2014 (Figure 4). 


\section{Figure 4 | The increasing share of low-polluting cars in imports, 2009-14}

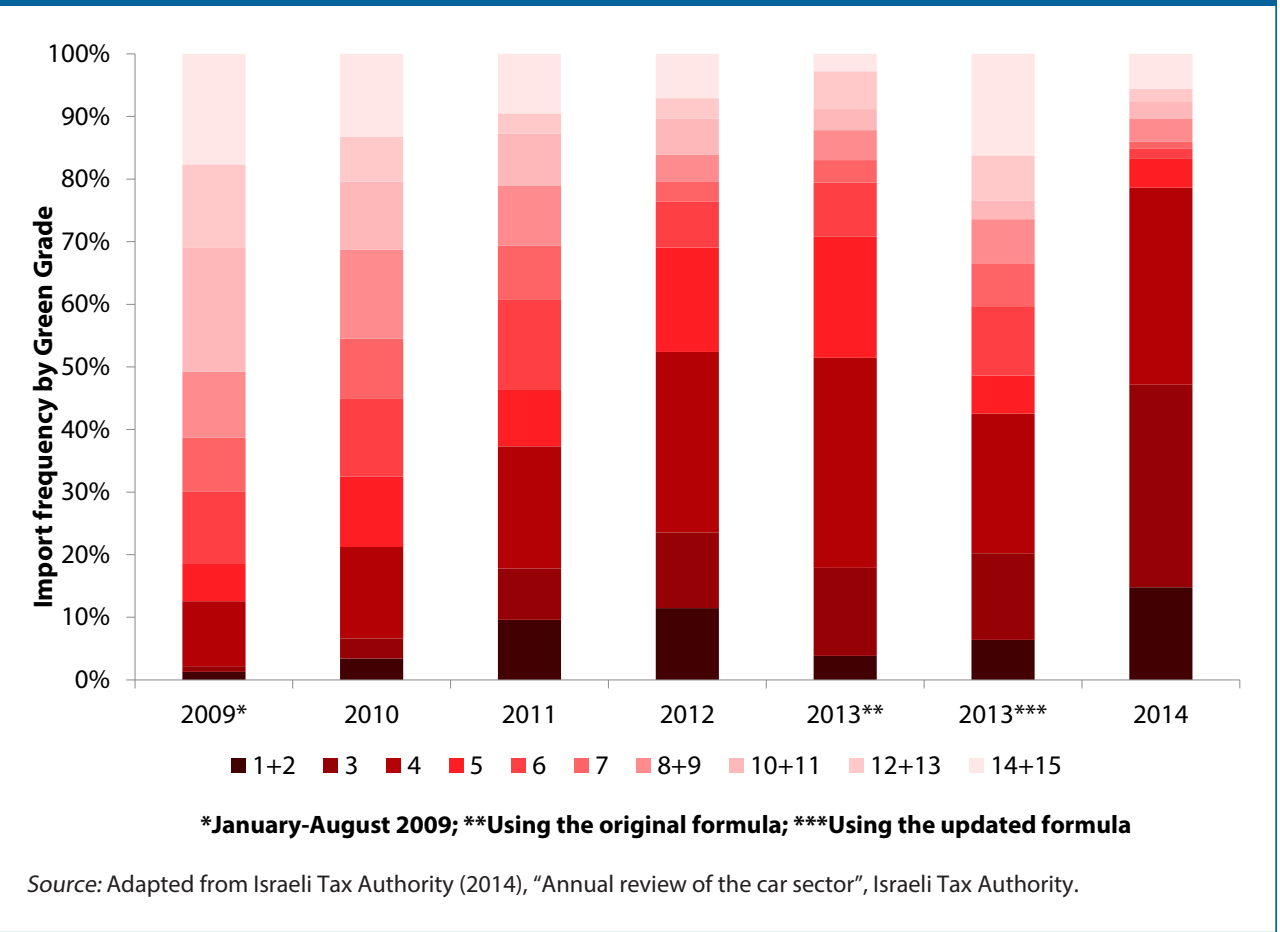

The share of heavy-polluting cars (bands 13-15) was reduced from 23.5\% in Jan-Aug 2009 to $7.4 \%$ (according to the original formula) in 2014, while the share of low-polluting vehicles went from $1.8 \%$ to $47.2 \%$.

As Table 5 shows, there has been an impressive $21 \%$ reduction in average $\mathrm{CO}_{2}$ emissions per car (from $178 \mathrm{~g} / \mathrm{km}$ to $140 \mathrm{~g} / \mathrm{km}$ ), although Israel has still not reached the average $\mathrm{CO}_{2}$ target of $130 \mathrm{~g} / \mathrm{km}$ set in Europe. A significant success is the drastic reduction in per car health-related emissions, particularly $\mathrm{NO}_{\mathrm{x}}$ and $\mathrm{PM}$. This contrasts with what has happened in many EU countries, where tax incentives based solely on $\mathrm{CO}_{2}$ emissions caused a dangerous increase in local air pollution by increasing the relative demand for diesel vehicles (which tend to emit less $\mathrm{CO}_{2}$, but more local pollutants than petrol cars).

However, the substantial increase in the total number of cars being purchased and the high overall traffic density in Israel has increased emissions overall and created secondary "rebound" effects in the form of increasing congestion of roads, thus increasing emissions even more. According to Table 6, which summarises total emissions from new cars (per km travelled), apart from PM emissions - which decreased by $24.2 \%$ 
overall - all other emissions went up, particularly CO. It is also evident that in the first year after the reform, as well as a year after the formula update, the market reacted to the tax cuts on lower emitting cars by a significant increase in the number of imported cars; this was accompanied by an increase in total emissions. Nevertheless, healthrelated pollution increased by a lower degree than $\mathrm{CO}_{2}$ emissions, and even decreased for PM. This contrasts with $\mathrm{CO}_{2}$-focused schemes, which have been shown to increase local pollution.

\section{Table 5 | Average (per car) emissions from new registered passenger cars fell significantly, 2009-14}

\section{Average emission level (g/km)}

\begin{tabular}{|ccccccc}
\hline Year & New registrations & $\mathrm{CO}_{2}$ & $\mathrm{HC}$ & $\mathrm{PM}$ & $\mathrm{NO}_{\mathbf{x}}$ & $\mathrm{CO}$ \\
\hline 2009 & 169426 & 178 & .049 & .00053 & .028 & .351 \\
\hline 2010 & 209185 & 170 & .047 & .00066 & .025 & .337 \\
\hline 2011 & 216068 & 160 & .043 & .00049 & .022 & .356 \\
\hline 2012 & 198271 & 152 & .042 & .00024 & .024 & .363 \\
\hline 2013 & 206075 & 144 & .038 & .00020 & .024 & .344 \\
\hline 2014 & 235269 & 140 & .037 & .00029 & .021 & .338 \\
\hline $\begin{array}{c}\text { \% change } \\
\text { (2009-14) }\end{array}$ & $\mathbf{3 9 \%}$ & $\mathbf{- 2 1 \%}$ & $\mathbf{- 2 4 \%}$ & $\mathbf{- 4 5 \%}$ & $\mathbf{- 2 5 \%}$ & $\mathbf{- 4 \%}$ \\
\hline
\end{tabular}

Source: Israeli Tax Authority (2015), "Annual review of the car sector" (in Hebrew), Tax Authority, https://taxes.gov.il/About/PeriodicReports/Pages/TaxesAboutTkufatiSkiraRehev.aspx.

Table 6 | Most overall emissions from new registered passenger cars have increased, 2009-14

\begin{tabular}{|cccccc}
\hline Year & New registrations & \multicolumn{5}{c}{ Total emission level $(\mathrm{g} / \mathrm{km})$} \\
\hline & & $\mathbf{C O}_{\mathbf{2}}$ & $\mathbf{H C}$ & $\mathbf{P M}$ & $\mathbf{N O}_{\mathbf{x}}$ \\
\hline 2009 & 169426 & 30115848 & 8280 & 90 & 4806 \\
\hline 2010 & 209185 & 35661756 & 9748 & 137 & 5170 \\
\hline 2011 & 216068 & 34493734 & 9362 & 105 & 4791 \\
\hline 2012 & 198271 & 30050734 & 8348 & 47 & 4672 \\
\hline 2013 & 206075 & 29652857 & 7897 & 42 & 4936 \\
\hline 2014 & 235269 & 33023327 & 8687 & 68 & 4984 \\
\hline $\begin{array}{c}\text { \% change } \\
\text { (2009-14) }\end{array}$ & $\mathbf{3 9 \%}$ & $\mathbf{9 . 7 \%}$ & $\mathbf{4 . 9 \%}$ & $\mathbf{- 2 4 . 2 \%}$ & $\mathbf{3 . 7 \%}$ \\
\hline
\end{tabular}

Source: Israeli Tax Authority (2015), "Annual review of the car sector" (in Hebrew), Tax Authority, https://taxes.gov.il/About/PeriodicReports/Pages/TaxesAboutTkufatiSkiraRehev.aspx. 
The difference in the rates of change in total emissions of various pollutants in Israel is important. It is positive that harmful PM emission levels went down and that extremely harmful $\mathrm{NO}_{\mathrm{x}}$ increased less than $\mathrm{CO}_{2}$. One of the reasons for this is that, unlike in Europe, Israeli consumers did not switch to diesel vehicles. Diesel cars, even though they produce significantly less $\mathrm{CO}_{2}$, emit several times more $\mathrm{NO}_{\mathrm{x}}$, which contributes to the formation of secondary PM (Hunt et al., 2016). In Europe, where $\mathrm{CO}_{2}$ reduction targets for the vehicle fleet were adopted in the 1990s alongside $\mathrm{CO}_{2}$-based taxation, diesel cars were seen as a cheap and easy way to achieve the targets. In these countries, $\mathrm{CO}_{2}$ taxation policy caused a shift to diesel vehicles. This was coupled with policies providing subsidies to manufacturers and for keeping diesel fuel prices below those of petrol. The switch to diesel subsequently increased the emissions of health-damaging pollutants.

Roshal and Tovias (2016) modelled the likely level of emissions if the Israeli scheme had focused solely on $\mathrm{CO}_{2}$ instead of imposing a tax on all the major pollutants. It is reasonable to assume that consumers would have switched to diesel cars, as happened in the EU. Between 2009 and 2014, approximately 2\% of all cars in Israel had diesel engines (ranging between $1 \%$ and $3 \%$ over the six years). The model assumes that a diesel car emits less $\mathrm{CO}_{2}, \mathrm{CO}$ and $\mathrm{HC}$, but more $\mathrm{NO}_{\mathrm{x}}$ and $\mathrm{PM}$ than a petrol car. In several European countries, the share of diesel cars is above 60\% (Belgium, France, Greece, Ireland, Luxembourg, Portugal, Spain), and in some others it is close to 50\% (Austria, Germany, Italy, Sweden, United Kingdom) (ACEA, 2015b). The modelling compared a range of scenarios for Israel - from the more likely (a 30\% share of diesel cars) to the more extreme but still possible (a $60 \%$ share) - with the actual situation (a 2\% share) (Table 7). 


\begin{tabular}{|c|c|c|c|c|c|c|c|}
\hline \multirow{2}{*}{ Table 7} & \multicolumn{7}{|c|}{$\%$ diesel cars in imports } \\
\hline & $2 \% 0$ & $10 \%$ & $20 \%$ & $30 \%$ & $40 \%$ & $50 \%$ & $60 \%$ \\
\hline Total number new cars & 1332555 & 1332555 & 1332555 & 1332555 & 1332555 & 1332555 & 1332555 \\
\hline Average $\mathrm{CO}_{2}(\mathrm{~g} / \mathrm{km})$ & 155.9 & 153.1 & 149.8 & 146.4 & 143.1 & 139.7 & 136.4 \\
\hline Average $\mathrm{HC}(\mathrm{g} / \mathrm{km})$ & 0.042 & 0.041 & 0.040 & 0.039 & 0.038 & 0.036 & 0.035 \\
\hline Average PM (g/km) & 0.000 & 0.000 & 0.001 & 0.001 & 0.001 & 0.001 & 0.001 \\
\hline Average $\mathrm{NO}_{\mathrm{x}}(\mathrm{g} / \mathrm{km})$ & 0.024 & 0.034 & 0.046 & 0.058 & 0.070 & 0.082 & 0.094 \\
\hline Average CO (g/km) & 0.348 & 0.338 & 0.327 & 0.316 & 0.305 & 0.294 & 0.282 \\
\hline Total $\mathrm{CO}_{2}$ (tonne/km) & 208 & 204 & 200 & 195 & 191 & 186 & 182 \\
\hline Total HC (g/km) & 56255 & 54919 & 53302 & 51685 & 50068 & 48451 & 46834 \\
\hline Total PM (g/km) & 524 & 605 & 702 & 800 & 898 & 996 & 1094 \\
\hline Total $\mathrm{NO}_{\mathrm{x}}(\mathrm{g} / \mathrm{km})$ & 31588 & 44963 & 61144 & 77326 & 93507 & 109688 & 125869 \\
\hline Total CO (g/km) & 463150 & 450838 & 435942 & 421046 & 406149 & 391253 & 376357 \\
\hline Total cost* & 25541 & 26142 & 26869 & 27596 & 28322 & 29049 & 29776 \\
\hline Cost of $\mathrm{CO}_{2}$ & 19897 & 19545 & 19119 & 18693 & 18266 & 17840 & 17414 \\
\hline Cost of non- $\mathrm{CO}_{2}$ & 5644 & 6597 & 7750 & 8903 & 10056 & 11209 & 12362 \\
\hline \multicolumn{2}{|l|}{$\begin{array}{l}\text { Difference in total cost } \\
\text { between } 2 \% \text { and each } \\
\text { subsequent scenario }\end{array}$} & $2.4 \%$ & $5.2 \%$ & $8.0 \%$ & $10.9 \%$ & $13.7 \%$ & $16.6 \%$ \\
\hline \multicolumn{2}{|l|}{ In cost of $\mathrm{CO}_{2}$} & $-1.8 \%$ & $-3.9 \%$ & $-6.1 \%$ & $-8.2 \%$ & $-10.3 \%$ & $-12.5 \%$ \\
\hline \multicolumn{2}{|l|}{ In cost of non- $-\mathrm{CO}_{2}$} & $16.9 \%$ & $37.3 \%$ & $57.8 \%$ & $78.2 \%$ & $98.6 \%$ & $119.0 \%$ \\
\hline \multicolumn{8}{|c|}{$\begin{array}{l}\text { Notes: *2013 costs, published by the MoEP, are used for simplicity. The costs (ILS per tonne) are: } 103 \text { for CO2; } 21454 \\
\text { for HC; } 145772 \text { for PM; } 75461 \text { for NOX; } 1042 \text { for CO. Source: MoEP (2013), webpage (in Hebrew), www.sviva.gov.il/ } \\
\text { subjectsEnv/SvivaAir/Pages/AirExternalCost.aspx. } \\
\text { (i) Average percentage of diesel cars in imports between } 2009 \text { and } 2014 .\end{array}$} \\
\hline
\end{tabular}

The calculations indicate that with $60 \%$ of diesel cars in the share of imports, the volume of PM emissions would be twice as high, and $\mathrm{NO}_{\mathrm{x}}$ emissions would be four times as high. This points clearly to the danger to public health of programmes based solely on $\mathrm{CO}_{2}$ emissions. But even in less extreme scenarios, the benefit of reductions in $\mathrm{CO}_{2}$ from a switch towards diesel vehicles does not compensate for the cost of increasing healthrelated pollution.

Thus by including the local air pollutants in the scheme, Israel has managed to reduce $\mathrm{CO}_{2}$ emissions per vehicle significantly, without causing additional damage to public health. Compared to the schemes that many EU countries have applied, this is probably the most important impact of the Israeli scheme, and makes Israel a pioneer in such emission-inclusive vehicle taxes. 


\section{Economic impacts}

As Israel's car market is entirely import-based (Box 1), the main economic impacts of the Green Tax are on tax revenues. Taxes on vehicles are an important source of revenue for the Israeli government. In Israel, vehicle taxation covers the whole spectrum of consumption taxes, including a purchase tax, customs duty and VAT on the final car price, all of which essentially more than double the (CIF) $)^{5}$ car price. This is in addition to an annual registration renewal tax and an excise on petrol. With the continuous rise in car imports, tax revenues had been increasing prior to the Green Tax reform, reaching a peak in 2007, when tax credits for the installation of safety mechanisms were introduced, thus reducing the effective tax. This was accompanied by the decreasing tax rate as part of a five-year tax-reduction plan (Box 3). By 2009, the purchase tax rate was $95 \%$ of the private car value, and 75\% on commercial vehicles, the highest in the OECD, except for Denmark and Norway (Table 9).

\section{Box 3 | Israel's 2005 purchase tax reform}

In 2005 - four years before the Green Tax reform was implemented - the realisation that older cars are both less safe and emit more pollution than new cars led to the major decision to reduce the purchase tax on motor vehicles in order to allow consumers to buy newer vehicles and to give tax incentives to install safety accessories. The purchase tax on private cars was cut by $6 \%$, from $95 \%$ to $89 \%$ for private and light commercial vehicles (not exceeding 3.5 tonnes), and the purchase tax rate on commercial vehicles was reduced from $75 \%$ to $73 \%$. The process was supposed to be spread over five years; the slow implementation aimed to avoid expectations that would lead to unwanted demand shifts. At the end of the period, by 2010, the purchase tax on private cars and commercial vehicles was to reach a uniform $72 \%$. However, the Green Tax reform came into force one year before the completion of the reform - in 2009. Additional tax credits were to be granted to those who installed safety accessories in their vehicles.

One of the main aims of the 2005 reform was to reduce car accidents; therefore no differentiation was created between vehicles according to their pollution levels. The cost of the reform in terms of lost revenues was estimated to be ILS 50 million in the first year, and ILS 100 million in 2007-10 (approximately EUR 9 million and EUR 18 million respectively).

Although the 2009 Green Tax reform was designed to be a revenue-neutral bonus-malus system (see section below on 'Comparison with other countries'), it turned out to be a net subsidy for new vehicle purchases. Immediately after the reform, there was a sharp increase in tax revenues due to an initial rise in sales as prices fell for the average family car. This was followed by a steep decline in revenues when consumers started to switch to cheaper, less polluting vehicles. Even though the number of imported vehicles 
increased by 7.6\% between 2008 and 2012 (Figure 5), total revenues dropped by nearly $13 \%$. The average effective tax rate went down from $73.1 \%$ to $61.3 \%$ - essentially, a much lower level than the intended final tax contemplated in the 2005 tax reduction reform (of $72 \%$, see Box 3). In 2012, total annual revenue from all vehicle taxes was about ILS 33.7 billion, or 3.6\% of Israel's GDP that year. The purchase tax on vehicles came to ILS 7.4 billon, $54 \%$ of all purchase tax revenues excluding fuel, or $0.6 \%$ of GDP that year.

\section{Figure 5 | The impact of tax reforms on car purchases, 2004-15} New car registrations per capita, 6-month moving average

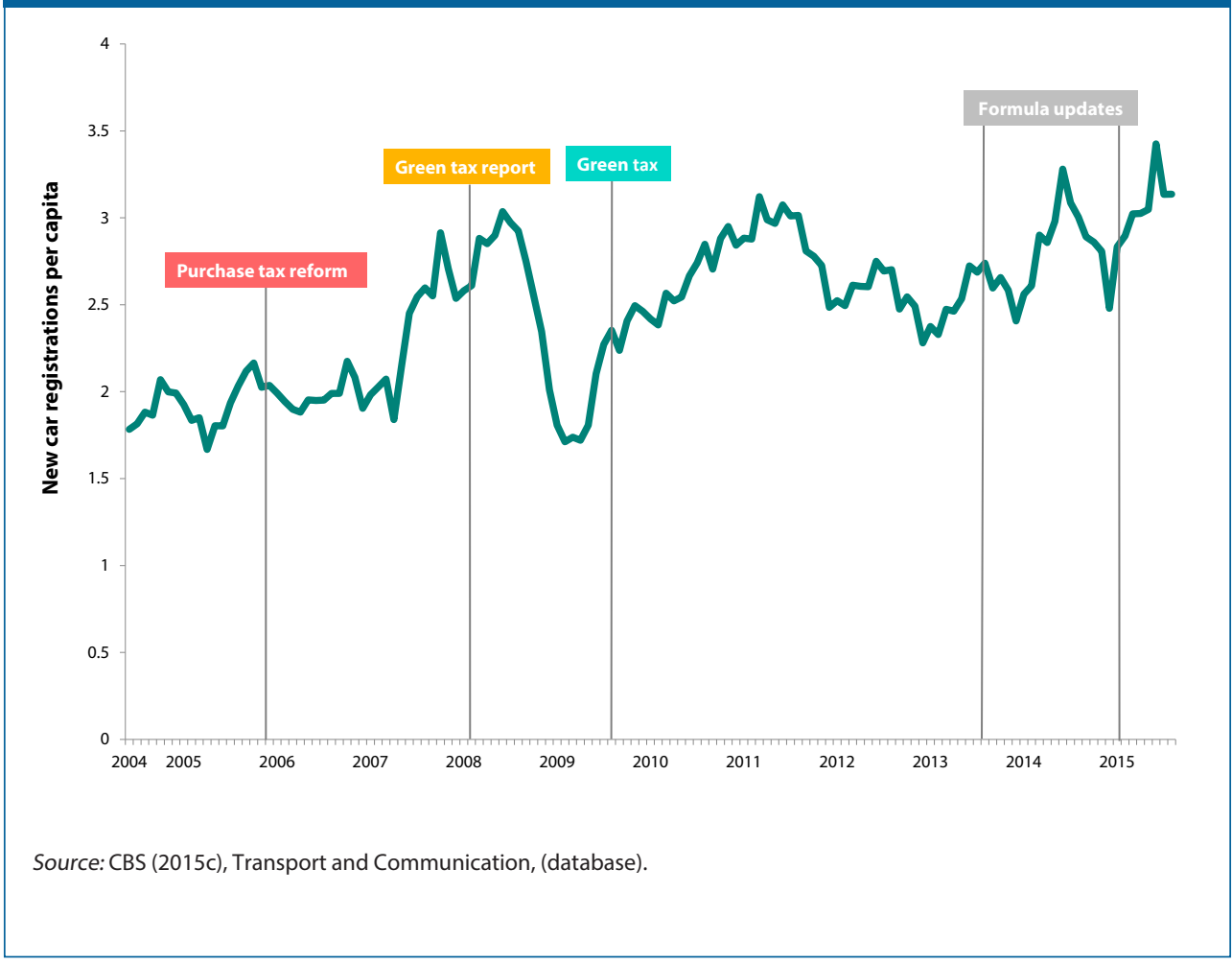


The research also explored what tax revenues would have looked like between 2009 and 2014 if the Green Tax reform had not been implemented. As with the assessment of the impacts on various emission categories, three different scenarios were considered, all with an average effective tax level of 70\% over the five years studied (the rate in 2009):

- Scenario 1 assumes that the amount and distribution of cars remained the same as in 2009.

- Scenario 2 assumes that the number of cars sold was the same as the actual situation between 2009 and 2014 (adjusting the value of the car in each year for inflation).

- Scenario 3 assumes that the number of cars grows by $4 \%$ each year, i.e. at a much lower rate than the actual situation.

Scenario 1 shows there would have been a considerable increase in income (ILS 2.5 billion) compared to the actual situation in the first two years, and an additional ILS 2.2 billion in 2014 compared to the situation after the formula change (Table 8). The hypothetical "losses" in 2012-2013 are incomparably smaller. This compares to the more extreme Scenario 2, where the estimated losses would reach ILS 11.4 billion over the five years. Under the more reasonable assumption of Scenario 3 (4\% annual growth in the number of cars), however, a mixed picture is observed again. There is a significant gain in the first year after implementation, followed by considerable loss. Thus although in the short term the reform would bring additional income, the net effect on revenues would be negative. The programme would only stay revenue-neutral if the annual growth in the number of cars was around 3\%.

Sharply decreasing revenues (of ILS 1.5 billion between 2010 and 2012) were one of the reasons for the green grade formula update in 2013, and the subsequent decision to update the formula every two years. 
Table 8 | Simulated effect of the Green Tax on revenues from purchase tax and VAT

ILS million, 2014 prices

\begin{tabular}{|c|c|c|c|c|c|c|c|}
\hline Year & 2009 & 2010 & 2011 & 2012 & 2013 & 2014 & Total \\
\hline \multicolumn{8}{|l|}{ Actual numbers } \\
\hline Total new cars & 172459 & 221923 & 229944 & 203727 & 225297 & 279205 & 1332555 \\
\hline Value of imports & 10634 & 12646 & 12783 & 11592 & 11859 & 14754 & 74268 \\
\hline Effective tax rate & $70 \%$ & $67 \%$ & $63 \%$ & $61 \%$ & $60 \%$ & $61 \%$ & \\
\hline Average car value & 61663 & 56983 & 55593 & 56901 & 52635 & 52843 & \\
\hline Purchase tax revenue & 7406 & 8521 & 8095 & 7110 & 7073 & 8934 & 47139 \\
\hline VAT revenue & 1702 & 2023 & 2045 & 1893 & 2085 & 2656 & 12404 \\
\hline Total revenue & 9108 & 10544 & 10140 & 9004 & 9158 & 11590 & 59544 \\
\hline \multicolumn{8}{|c|}{$\begin{array}{l}\text { Scenario } 1 \text { (base): same number of cars } \\
\text { as in 2009; effective tax as in } 2009(70 \%)\end{array}$} \\
\hline Total new cars & 172459 & 172459 & 172459 & 172459 & 172459 & 172459 & 1034754 \\
\hline Value of imports & 10634 & 10634 & 10634 & 10634 & 10634 & 10634 & 63806 \\
\hline Average car value & 61663 & 61663 & 61663 & 61663 & 61663 & 61663 & \\
\hline Purchase tax revenue & 7406 & 7406 & 7406 & 7406 & 7406 & 7406 & 44438 \\
\hline $\begin{array}{l}\text { Purchase tax difference between actual } \\
\text { and scenario }\end{array}$ & & 1115 & 689 & -296 & -334 & 1528 & 2702 \\
\hline VAT revenue & 1702 & 1702 & 1702 & 1737 & 1870 & 1914 & \\
\hline Total revenue & 9108 & 9108 & 9108 & 9143 & 9276 & 9320 & 55063 \\
\hline Revenue difference & & 1437 & 1032 & -139 & -118 & 2269 & 4481 \\
\hline \multicolumn{8}{|c|}{$\begin{array}{l}\text { Scenario 2: same number of cars as } \\
\text { actual; effective tax as in } 2009(70 \%)\end{array}$} \\
\hline Total new cars & 172459 & 221923 & 229944 & 203727 & 225297 & 279205 & 1332555 \\
\hline Value of imports & 10634 & 13685 & 14179 & 12562 & 13893 & 17217 & 82170 \\
\hline Average car value & 61663 & 61663 & 61663 & 61663 & 61663 & 61663 & \\
\hline Purchase tax revenue & 7406 & 9531 & 9875 & 8749 & 9675 & 11991 & 57227 \\
\hline $\begin{array}{l}\text { Purchase tax difference between actual } \\
\text { and scenario }\end{array}$ & & -1010 & -1780 & -1639 & -2603 & -3057 & -10087 \\
\hline VAT revenue & 1702 & 2190 & 2269 & 2052 & 2443 & 3099 & \\
\hline Total revenue & 9108 & 11720 & 12144 & 10801 & 12118 & 15090 & 70980 \\
\hline Revenue difference & & -1176 & -2003 & -1797 & -2960 & -3500 & -11436 \\
\hline \multicolumn{8}{|c|}{$\begin{array}{l}\text { Scenario 3: number of cars grows annu- } \\
\text { ally by } 4 \% \text {; effective tax as in } 2009(70 \%)\end{array}$} \\
\hline Total new cars & 172459 & 179357 & 186532 & 193993 & 201753 & 209823 & 1143916 \\
\hline Value of imports & 10634 & 11060 & 11502 & 11962 & 12441 & 12938 & 70538 \\
\hline Average car value & 61663 & 61663 & 61663 & 61663 & 61663 & 61663 & \\
\hline Purchase tax revenue & 7406 & 7703 & 8011 & 8331 & 8664 & 9011 & 49126 \\
\hline $\begin{array}{l}\text { Purchase tax difference between actual } \\
\text { and scenario }\end{array}$ & & 818 & 84 & -1221 & -1592 & -77 & -1986 \\
\hline VAT revenue & 1702 & 1770 & 1840 & 1954 & 2187 & 2329 & \\
\hline Total revenue & 9108 & 9472 & 9851 & 10285 & 10852 & 11340 & 60907 \\
\hline Revenue difference & & 1072 & 289 & -1281 & -1694 & 250 & -1364 \\
\hline VAT (average) & $16.0 \%$ & $16.0 \%$ & $16.0 \%$ & $16.3 \%$ & $17.6 \%$ & $18.0 \%$ & \\
\hline
\end{tabular}

*Revenue-neutral scenario over 5 years would assume annual growth in the number of cars $=3.1 \%$. If only purchase tax taken into account, annual growth in the number of cars $=2.3 \%$. ${ }^{* *}$ VAT revenues are calculated using VAT rate in a specific year multiplied by the price of the car and number of cars sold., ${ }^{* *}$ Customs excluded from calculation; average car assumed to be the same as in 2009 , therefore no influences from gas prices, income, changes in preferences and other shocks to the system are assumed. 


\section{Social impacts}

Compared to revenue-generating taxes, environmental tax reforms like the Green Tax reform increase wellbeing by reducing pollution, and increase welfare by ensuring that the costs to society of polluting are covered by the tax on cars. The main concern of the Green Tax commission was to eliminate the subsidy provided by society for car users, who do not face the full costs of their vehicle use. If tax revenues could be (hypothetically) directed to specific uses, one of which would be to cover the costs to society from the use of private cars, then by simply combining the effects of the reform on total pollution (Table 7) and total revenues (Table 8) and evaluating whether the gains (or losses) of revenues did actually cover the losses (or gains) of the externalities, it is possible to determine whether the Green Tax achieved this goal. To explore this, three further scenarios were modelled by Roshal and Tovias (2016). The results of Scenario 3 (the scenario probably closest to the real effect of the reform) confirm that the reform is likely to have created more costs to society in terms of pollution than revenues gained to cover these costs. In the first two years additional revenues did cover additional costs, but the effect turned negative from 2014.

For a complete picture, however, two additional points should be made. First, the effect of reduced average car prices and an increase in the number of cars sold would potentially benefit the welfare of a larger group of people. And second, even though the programme led to a net subsidy for the purchase of new vehicles, the impact on local air pollution was less than in similar schemes in other countries.

\section{Comparison with other countries}

Economic instruments like vehicle taxation based on fuel consumption and, recently, $\mathrm{CO}_{2}$ emissions have been in increased use worldwide to encourage the purchase of lowemission cars, either in the form of a one-off purchase tax, or as part of an annual or recurring registration fee. Some countries have introduced a measure of differentiation in both taxes. "Feebate" (bonus/malus) schemes have recently been employed in some countries, such as France, Canada and the Netherlands (Table 9). ${ }^{6}$ Under such schemes, rebates are offered to the buyers of vehicles with low $\mathrm{CO}_{2}$ emissions, and taxes are imposed on purchasers of gas-guzzlers. The important difference between the Israeli scheme and similar schemes in other countries aiming to reduce mainly $\mathrm{CO}_{2}$ is that Israel incorporated health-related emissions alongside $\mathrm{CO}_{2}$ in the tax formula, thus deterring the shift towards diesel cars while also reducing greenhouse gas emissions. 


\section{Table 9 | Private car taxes in selected countries 2014}

\begin{tabular}{|c|c|c|c|}
\hline Country & Min & Max & Notes \\
\hline Austria & & & $\begin{array}{l}\text { Based on } \mathrm{CO}_{2}, \mathrm{NO}_{x} \text { and } \mathrm{PM} \text { emissions + bonus/malus, different for } \\
\text { diesel vehicles }\end{array}$ \\
\hline Belgium & & & $\begin{array}{l}\text { Based on } \mathrm{cc}+\text { age; } \mathrm{CO}_{2} \text { emissions (Wallonia) } \\
\mathrm{CO}_{2}+\text { Euro standards }+ \text { fuel }+ \text { age (Flanders) }\end{array}$ \\
\hline Denmark & $105 \%$ & $180 \%$ & $\begin{array}{l}\text { Registration: } 105 \% \text { of up to DKK } 80500+180 \% \text { on the remainder, } \\
\text { based on fuel consumption and different for diesel vehicles; } \\
\text { credits for safety systems. Annual progressive tax based on fuel } \\
\text { consumption, different for petrol and diesel }\end{array}$ \\
\hline Finland & $5 \%$ & $50 \%$ & $\begin{array}{l}\text { Registration tax based on Price }+\mathrm{CO}_{2} \text { emissions; recurring tax } \\
\text { based on } \mathrm{CO}_{2} \text { emissions }\end{array}$ \\
\hline France & EUR 150 & EUR 8000 & $\begin{array}{l}\text { Registration based on } \mathrm{CO}_{2} \text { emissions (bonus/malus) and annual tax } \\
\text { based on } \mathrm{CO}_{2} \text { emissions }\end{array}$ \\
\hline Germany & & & No registration tax; recurring tax based on $\mathrm{CO}_{2}$ emissions \\
\hline Greece & $5 \%$ & $50 \%$ & $\begin{array}{l}\text { Registration taxes based on cc + EURO standard; annual taxes } \\
\text { based on } \mathrm{cc}^{2} \text { and } \mathrm{CO}_{2} \text { emissions (for newer cars) }\end{array}$ \\
\hline Ireland & $14 \%$ & $36 \%$ & $\begin{array}{l}\text { Progressive registration tax based on } \mathrm{CO}_{2} \text { emissions; annual pro- } \\
\text { gressive tax based on } \mathrm{CO}_{2} \text { emissions }\end{array}$ \\
\hline Italy & & & Based on kilowatt, weight, seats \\
\hline Luxembourg & & & Recurring tax based on $\mathrm{CO}_{2}$ emissions; higher for diesel vehicles \\
\hline Netherlands & & & $\begin{array}{l}\text { Based on price }+\mathrm{CO}_{2} \text { emissions, slightly higher for diesel; relatively } \\
\text { high registration and annual circulation tax for non-electric/hybrid }\end{array}$ \\
\hline Norway & & & $\begin{array}{l}\text { Progressive registration tax based on weight, engine power, } \mathrm{NO}_{\mathrm{x}^{\prime}} \\
\mathrm{CO}_{2} \text { emissions; can be as much as } 50 \% \text { of the vehicle total price }\end{array}$ \\
\hline Portugal & & & $\begin{array}{l}\text { Progressive registration tax based on } \mathrm{cc} \text { and } \mathrm{CO}_{2} \text {, higher for diesel; } \\
\text { annual tax based on } \mathrm{CO}_{2}\end{array}$ \\
\hline \multicolumn{4}{|c|}{$\begin{array}{l}\text { Source: ACEA (2015), “Overview of CO2-based motor vehicle taxes in the EU in 2015," } \\
\text { www.acea.be/uploads/publications/CO2_tax_overview_2015.pdf; ACEA (2014), ACEA Tax Guide } 201\end{array}$} \\
\hline
\end{tabular}

Israel has the advantage of being a small, import-based country that cannot affect supply and production standards; otherwise opposition to the reform would have probably included several additional bodies, mainly car manufacturers, focused on $\mathrm{CO}_{2}$ reductions. In larger countries, where demand can have an impact on manufacturers, the implementation of a similar tax would mean costly production adjustments; therefore any such scheme might require a directive on an international level. 
Israel's Green Tax reform was successful in shifting demand towards less polluting vehicles, proving the efficiency of economic incentives in changing behaviour. The negative environmental effects were the result of increasing demand, rather than a failure of the tax to create a shift from polluting cars. Nevertheless, a stronger increase in local pollution was avoided by integrating health-related pollutants in the scheme.

Israel's experience indicates that any public administration should be careful when designing a similar scheme to ensure that it does not reduce average car prices too much, in order to limit potential rebound effects. With GDP per capita continuing to grow and investment in infrastructure lagging behind the increase in car ownership, a further reduction of the purchase tax would mean even more vehicles on the road and a further increase of negative externalities.

The Israeli experience sets a precedent for creating an effective formula for a single tax that successfully integrates both greenhouse gases and local air pollutants, thus matching the marginal cost to society with the marginal cost of using the car. However, every market is different, both in terms of the relative costs to society of the various pollutants, and because car fleets are not solely determined by tax levels: family composition, urbanisation, efficiency and cost of public transport, as well as preferences and awareness, all determine the composition of car fleets and their use. What works in one country might not particularly be adaptable in another.

In order to adapt this policy to other OECD countries, some points need to be taken into account:

1. The tax formula should incorporate several pollutants weighted according to their cost to society. The formula should be country-specific, developed following an extensive study of the actual costs for each pollutant. If transferring a formula is necessary, it should be handled with great care to incorporate as much of the country-specifics as possible. Climate differences can aggravate the impact of pollutants. The share in the population of children, who are more susceptible to the effects of pollution and whose productive period lays in the future, increases the costs even more. A higher percentage of older people in the population adds to these - all these affect the weightings of the formula. 
2. To avoid the erosion of the tax base over time, the tax formula should be updated regularly, with the dates of the updates set in advance and according to pre-agreed procedures.

3. Politically, it is hard to impose higher taxes; the Israeli reform succeeded partially because of the prevalence of initially high tax rates that could be modified to create differentiation in tax rates, rather than bringing in higher taxes. Revenue-neutral schemes, however, although politically justified, might lead to higher total pollution than before the differentiation was created.

4. The Green Tax reform succeeded mainly due to extensive co-operation between various bodies: the Israeli Tax Authority, ministries of Finance, Environmental Protection, Transport and Infrastructure, and others. Car importers and manufacturers should also be involved in order to ensure their co-operation in supplying a reliable source of emission data for each car (with the testing being performed by an independent tester).

5. A reliable and transparent database should be built and managed by the relevant authorities. These authorities should also be responsible for raising public awareness of tax incentives by compulsory and clear advertisement of tax bands and pollution levels. Authorities should also make their calculations publicly available.

6. The Israeli experience shows that there could be strong opposition to the tax, mainly from the supply side. It might be harder to introduce a tax based on emissions other than $\mathrm{CO}_{2}$ in markets where there is substantial manufacturing focused on $\mathrm{CO}_{2}$ efficiency. An international directive (at the EU level, for example), might help to promote this kind of measure. In Israel, the thorough analysis of the external costs produced by all the pollutants and the necessity to internalise all of them, as outlined in the Green Tax report, helped to overrule the opposition. This was also feasible because, unlike in Europe, the share of diesel vehicles in total car sales is very small.

7. If an annual tax is selected because it can be easily differentiated (instead of focusing on first-time registration or import taxes), relevant authorities should think in advance how to deal with changing grades in existing cars each time the formula is adjusted. Authorities should keep a history of grades if they wish to keep the annual tax unchanged for each individual vehicle as it ages. 
In Israel, future legislation should focus on regulating demand for using private vehicles, as suggested in the OECD Economic Survey of Israel (OECD, 2013). The Green Tax Report (2008) proposed several complementary steps to the Green Tax, and specified that any increase in car-related taxation should be accompanied by policies that offer viable alternatives, including: reducing vehicle-related employee benefits; developing public transport; reducing demand for motorised transport altogether by investing in cycling lanes, and in localised business areas and entertainment facilities. These should all be implemented to complement and strengthen the impact of the Green Tax.

\section{Notes}

1. The effective tax rate is the actual tax that remains after deducting from the base tax level of $83 \%$ the green grade rebates and tax credits for any additional safety systems.

2. In practice, limited information on heavy vehicles and the lack of "green" alternatives prevented the tax on these vehicles from being increased.

3. For full details on the in-depth methodology used in thwe new study, see Roshal and Tovias (2016).

4. For a full list of the updated grades see Roshal and Tovias (forthcoming).

5. Cost, insurance and freight.

6. For a comprehensive comparison of various taxes and their progressive effects, see Braathen (2009). 
ISRAEL'S GREEN TAX ON CARS: LESSONS IN ENVIRONMENTAL POLICY REFORM 


\section{References}

ACEA (2015), "Overview of $\mathrm{CO}_{2}$-based motor vehicle taxes in the EU in 2015", European Automobile Manufacturers Association, Brussels, www.acea.be/uploads/publications/CO2_tax_overview_2015.pdf.

ACEA (2014), ACEA Tax Guide 2014, European Automobile Manufacturers Association, Brussels.

Braathen, N. A. (2009), "Incentives for $\mathrm{CO}_{2}$ emission reductions in current motor vehicle taxes," Working Party on National Environmental Policies and Working Group on Transport, OECD, Paris, http://tinyurl.com/zqwpkkm.

CBS (2015a), Motor Vehicles 2014, database, Central Bureau of Statistics, http://cbs.gov.il/webpub/pub/text_page_eng.html?publ=13\&CYear=2014\&CMonth=12.

CBS (2015b), Table 27.6 in Statistical Abstract of Israel, Central Bureau of Statistics, http://cbs.gov.il/shnaton66/st27_06.pdf.

CBS (2015c), Transport and Communication, (database), Central Bureau of Statistics.

FT (2015), "VW scandal set to choke diesel car industry," Financial Times, 22 September 2015, http://tinyurl.com/hxxatpz.

Green Tax Report (2008), "Report of the inter-ministerial commission for Green Taxation," Israeli Tax Authority, Ministry of Finance, Ministry of Transport, Ministry of Infrastructure and Ministry for Environmental Protection (in Hebrew), http://taxes.gov.il/About/Documents/DochotVaadot/misui150108_11.pdf.

Hunt, A. et al. (2016), "Social costs of morbidity impacts of air pollution", OECD Environment Working Papers, No. 99, OECD Publishing, Paris, DOI: http://dx.doi.org/10.1787/5jm55j7cq0lv-en.

Israeli Tax Authority (2015), "Annual review of the car sector" (in Hebrew), Tax Authority, https://taxes.gov.il/About/PeriodicReports/Pages/TaxesAboutTkufatiSkiraRehev.aspx.

Israeli Tax Authority (2010a), "Annual review of the car sector" (in Hebrew), Tax Authority, https://taxes.gov.il/About/PeriodicReports/Pages/TaxesAboutTkufatiSkiraRehev.aspx.

Israeli Tax Authority (2010b), “Taxes and overview of the car sector, 2010”, Tax Authority.

OECD (2015), Environment at a Glance 2015: OECD Indicators, OECD Publishing, Paris, http://dx.doi.org/10.1787/9789264235199-en.

OECD (2013), OECD Economic Surveys: Israel 2013, OECD Publishing, Paris, http://dx.doi.org/10.1787/eco_surveys-isr-2013-en.

Roshal, V. and A. Tovias (2016), "Car purchase tax: green tax reform in Israel”, OECD, Paris. 


\section{Israel's Green Tax on Cars}

\section{Lessons in Environmental Policy Reform}

\section{The OECD Environment Policy Papers}

Designed for a wide readership, the OECD Environment Policy Papers distil many of today's environment-related policy issues based on a wide range of OECD work. In the form of country case studies or thematic reviews across countries, the Papers highlight practical implementation experience. They are available in either English or French, with a summary in the other language when possible.

1. OECD (2013), "Climate and Carbon: Aligning Prices and Policies", OECD Environment Policy Papers, No. 1, OECD Publishing, DOI: 10.1787/5k3z11hjg6r7-en.

2. OECD (2013), "The Swedish Tax on Nitrogen Oxide Emissions: Lessons in Environmental Policy Reform", OECD Environment Policy Papers, No. 2, OECD Publishing, DOI: http:// dx.doi.org/10.1787/5k3tpspfqgzt-en.

3. OECD (2014), "Greening Household Behaviour: A review for policy makers", OECD Environment Policy Papers, No. 3, OECD Publishing, Paris, DOI: http://dx.doi. org/10.1787/5jxrcllp4gln-en.

4. OECD (2015), "The Lake Taupo Nitrogen Market in New Zealand: Lessons in Environmental Policy Reform", OECD Environment Policy Papers, No. 4, OECD Publishing, Paris, DOI: http://dx.doi.org/10.1787/5jrtg113p9mr-en.

5. OECD (2016), "Israel's Green Tax on Cars: Lessons in Environmental Policy Reform", OECD Environment Policy Papers, No. 5, OECD Publishing, Paris.

\section{Contacts}

For further information, please contact:

\section{Nils Axel Braathen}

Environmental Policy Analysis

OECD Environment Directorate

Tel.: +33 (0)1 45247697

Cover photo

Email: Nils-Axel.Braathen@oecd.org

(c) Istockphoto.com 